This is the accepted version of a forthcoming article that will be published by Taylor $\&$ Francis in Journal of North African Studies:

Accepted version downloaded from SOAS Research Online: http://eprints.soas.ac.uk/25444/

Hispano-Moroccan Mimesis in the Spanish War on Tetouan and its Occupation (1859-62)

Itzea Goikolea-Amiano

ERC MULOSIGE Post-Doctoral Fellow, Centre for Cultural, Literary and Postcolonial Studies (CCLPS), SOAS (University of London)

ig12@soas.ac.uk 
This is the accepted version of a forthcoming article that will be published by Taylor \& Francis in Journal of North African Studies:

Accepted version downloaded from SOAS Research Online: http://eprints.soas.ac.uk/25444/

\section{Hispano-Moroccan Mimesis in the Spanish War on Tetouan and its Occupation (1859-62) ${ }^{1}$}

\section{Abstract}

The 'War of Africa'/'War of Tetouan' (1859-60) and the subsequent Spanish occupation of Tetouan (1860-62) have commonly been considered the landmark of the end of Morocco's independence. While it is hardly arguable that Spain achieved to consolidate its position in Morocco throughout the second half of the nineteenth century thanks to the favorable conditions established in the treaties that followed the end of the war, the goal of this article is to nuance the reification of the power of the colonizers and the powerlessness of the colonized that many historiographical narratives have purported. I will concentrate on the initial stage of the occupation of Tetouan, and will illustrate the political transformation that took place among the Spaniards who were on the ground. Although I will mainly rely on Spanish sources, I will highlight the ways in which Makhzan diplomacy, Tetouani common people, and local notions and practices shaped such transformation by contributing to create and expand the anxieties and obstacles that permeated the Spanish colonization. I argue that the Spaniards who were on the ground increasingly empathized, self-identified, and admired Moroccans, and constructed Hispano-Moroccan analogy and similarity. Such colonial mimesis, performed by the Spanish colonizers, went hand in hand with the perception of Moroccans as unyielding, which led the Spanish to admit the difficulty, even impossibility, of their colonialist venture.

\section{Keywords}

Agency; colonization; mimesis; Spain; Morocco; Tetouan

${ }^{1}$ I would like to extend my sincere gratitude to Eric Calderwood and David Stenner for their thorough revision and suggestions. 
This is the accepted version of a forthcoming article that will be published by Taylor \& Francis in Journal of North African Studies:

Accepted version downloaded from SOAS Research Online: http://eprints.soas.ac.uk/25444/

\section{Introduction}

After weeks of unsuccessful diplomatic conversations, Spain officially declared war on Morocco on October 22, 1859. The negotiations had followed a reported aggression against a Spanish post in Ceuta by members of the Anjira tribe in August. Similar contentions had occurred in the previous decade against the backdrop of Spain's will to extend its control in Morocco to gain commercial trade shares and to legitimize its power vis-à-vis other European nations present in Morocco, particularly France which colonized Algeria since 1830 (Garrido Quijano 2014, 82-93). Sultan ‘Abd al-Raḥmān's death on August 22, 1859 proved beneficial to advance Spain's interests and, even if the commander in chief of the so-called Army of Africa, Leopoldo O'Donnell, declared the mission did not have "a conquest spirit," the flag-waving peninsular press and politicians hastened to encourage the Spanish troops' advancement beyond Tetouan, which was seized on February 6, 1860.

The armed conflict took place in the territory between Ceuta and the plain of Wad Ras, yet in Spain the setting of the war was written and spoken about as a synecdoche for the whole African continent, as the locution 'war of Africa' shows. In Morocco, the Arabic and Tamazight names given to the conflict translate as 'the war of Tetouan' (Ricard 1968, 5). Spanish and Moroccan historiographies have generally maintained such denominations, although several scholars have suggested alternative terms (Martínez Antonio 2010; Calderwood 2011). In this article, I will use the name 'Spanish war on Tetouan.' Firstly, because what happened was a unilateral Spanish militarized aggression (hence the selection of the preposition 'on') rather than a proper bilaterally-enhanced 
This is the accepted version of a forthcoming article that will be published by Taylor \& Francis in Journal of North African Studies:

Accepted version downloaded from SOAS Research Online: http://eprints.soas.ac.uk/25444/

armed conflict, and secondly, because to name a war that took place in a restricted area of northern Morocco after the whole African continent responds, as the war did, to colonialist concepts that take shape through language. ${ }^{2}$

The peacemaking negotiations began five days after Tetouan was seized, lasting for more than a month and a half, and concluding in the preliminary signature of the Treaty of Wad Ras on March 26, 1860. This article will concentrate on this initial stage of the Spanish occupation of Tetouan, in which the Spaniards who were on the ground steadily transformed their political stances. Ultimately, my twofold goal is to nuance the reification of the power of the colonizers and the powerlessness of the colonized purported by the historiographical narratives which have located the beginning of the end of Morocco's independence at the Spanish war on Tetouan; and to emphasize the role that Moroccan and specially Tetouani people, notions, and practices played in the occupational discourses and policies.

As a consequence of the influence that different categories of Moroccan people and politics had on them, the Spaniards who were in Tetouan in the initial stage of the occupation steadily softened their preliminary warmongering and boastful cries. They ceased to perceive Tetouanis as 'the enemy' (at least exclusively), and they turned to acknowledge their colonial limitations. The gradual and multifaceted transformation which took place among those military and civilian Spaniards is observable in their steady

\footnotetext{
${ }^{2}$ Although Tetouani historian Abdelaziz Assaoud has referred to the war in different ways, his choice in one of his papers is similar to mine. See Assaoud 2010.
} 
This is the accepted version of a forthcoming article that will be published by Taylor \& Francis in Journal of North African Studies:

Accepted version downloaded from SOAS Research Online: http://eprints.soas.ac.uk/25444/

emphasis on Hispano-Moroccan similarity. Although the literature on colonial mimesis and mimicry has mostly conceived of it as a subaltern strategy displayed by the colonized (Taussig 1993; Bhabha 1997), I contend that during the initial stage of the occupation of Tetouan it was the Spanish 'conquistadors' who mimicked the Moroccan colonized. They did so as a result of their increasing empathy, self-identification and admiration of Moroccans, especially Muslim Tetouani men, whom they came to conceive as 'unyielding.'

Mimesis has been variously conceptualized across disciplines. ${ }^{3}$ Essentially, mimesis is the representation of sameness, and has difference as its governing principle (Kelly 1998, III: 237). This simple definition points to two key concepts, sameness and difference, and to their interrelatedness. Mimesis thus becomes key in both the construction of the radically different Other as well as in the challenging of it. This article will argue that Moroccan people and notions influenced Spaniards in such way that a transition can be noted from Spaniards' highlighting of Hispano-Moroccan difference to their increasing emphasis on similarity, affinity, and self-identification, on the one hand, and on their reproduction, appropriation and ventriloquization of Moroccans' claims, which shows the credibility and authority that the latter inspired to the occupiers, on the other hand.

\footnotetext{
${ }^{3}$ See, for example, Farneti 2015; Palaver 2013; Polat 2012; Fuchs 2001; Irigaray 1996; Taussig 1993; and Contagion: Journal of Violence, Mimesis, and Culture since 1994.
} 
This is the accepted version of a forthcoming article that will be published by Taylor \& Francis in Journal of North African Studies:

Accepted version downloaded from SOAS Research Online: http://eprints.soas.ac.uk/25444/

This article will look at the Spanish side of the conflict and will mainly rely on Spanish sources, but it will highlight the decisive role that Moroccans played in shaping the political transformation that can be seen in and through the Spanish texts. Although I will also point at other texts and authors, I will principally focus on Pedro Antonio de Alarcón and his 800-page Diary of a Witness of the War of Africa, which became a bestseller in the context of the patriotic fervor which overcame the Spanish peninsula with the announcement of the war. Born in 1833 in Guadix (Granada), Alarcón was a seminarian during his childhood and youth. Having abandoned the ecclesiastic domain, he moved to Madrid in 1854, where he founded an antimonarchist and revolutionary paper. Later on, Alarcón discarded liberal ideas. From 1875 on, he held different positions within O’Donnell's La Unión Liberal, both in Spain and abroad (Romano 1933).

Alarcón's work has been studied by many scholars, who have mostly looked at his jingoistic nationalistic and imperialistic cries. Some scholars, as Morales Lezcano (2004), have mentioned that he turned to pacifist positions towards the end of his stay in Tetouan without, however, explaining what might have driven him to do so. For her part, Susan Martín-Márquez has contended that his change in attitude was related to his religiously inflected colonial ideology, and that "Alarcón's call for war [wa]s lowered when he underst[ood] Jewish and Muslim will not convert [to Christianity] (...) [and] he must abandon the theatre of war in order to avoid his own dramatization of colonial conquest" $(2008,112-13)$. In my opinion, such interpretations fail to place the text in its context and consequently brand the discursive fractures that permeate Alarcón's Diary as eccentricities. Instead, my goal is to dispel linear or homogenizing depictions of both the 
This is the accepted version of a forthcoming article that will be published by Taylor \& Francis in Journal of North African Studies:

Accepted version downloaded from SOAS Research Online: http://eprints.soas.ac.uk/25444/

texts and the complex historical subjects which produced them, and to explain such transformations.

Notwithstanding, while the mimesis of the Spaniards who were influenced by Moroccan people and politics certainly presented subversive and threatening stands with regards to the Spanish state and especially liberal colonialist sectors, the restraint that they advocated was beneficial for the Spanish colonial project in Morocco. These Spaniards' pragmatism ultimately enabled the signature of the treaties that followed the war, which eventually eased the Spanish colonial penetration into Morocco in the second half of the nineteenth century. The 1860 Treaty of Wad Ras led to the establishment of new borders in which Spain gained territory, to new commercial agreements that were favorable for the Spanish, and it eased the reinforcement of the presence of Spanish Catholics in northern Morocco (Cagigas 1952). Besides, the Spanish occupation of Tetouan was redefined as a temporary warranty until the Morocco would have paid the war indemnity of 20 million reales but, as the Makhzan was unable to pay the sum, the new treaties signed throughout 1861 established the Spanish - and British - intervention of eight customs offices in coastal Morocco, which continued until the mid-1880s (Rodríguez Esteller 2002).

It is not my aim, therefore, to deny that Spain consolidated its influence in the Morocco throughout the second half of the nineteenth century thanks to the favorable conditions established in the treaties that followed the end of the war on Tetouan, as it has widely been considered. Rather, my goal is to show that the Spaniards faced colonizing difficulties and, especially, that the Spanish occupation of Tetouan was the 
This is the accepted version of a forthcoming article that will be published by Taylor \& Francis in Journal of North African Studies:

Accepted version downloaded from SOAS Research Online: http://eprints.soas.ac.uk/25444/

outcome of a complex negotiation, in which Moroccan and especially Tetouani people, notions, and practices played a vital role.

\section{The Capture of Tetouan: Imperial Grandiloquence and the Recreation of}

\section{Reconquista}

Vast crowds of Tetouani people carrying their furniture and possessions stretched out along the routes of exile on the eve and immediately after the Spanish capture of Tetouan. After the Moroccan breakdown in the so-called Battle of Tetouan, the political and religious authorities pushed for Tetouan to be emptied before the Spanish seizure (Ibn Khālid al-Nāșirī 1997, 9:90). Tetouani Muslims and Jews fled to Chefchaouen, Tangier, Gibraltar, El-Ksar el-Kebir and the villages in the surrounding northern Moroccan rural lands, and some also settled in neighbouring Algeria and the southern Spanish coastal towns (Daoud 1964a, V:227-31; Vilar 1985, 50). Although some Tetouanis remained in and others entered the city temporarily while the Spanish were in control, the majority of the population did not return home until the Spanish Forces of the Occupation had evacuated the city in May 1862.

The fluttering of the Spanish flag on top of the citadel of al-Manzari, named after the leader of the exiled Andalusis who had re-established Tetouan in the fifteenth century, signaled the Spanish capture of the city on February 6, 1860. The whole Army of Africa, scattered in different locations, celebrated the feat to the sound of the music played by the military orchestra. Pedro Antonio de Alarcón, the chronicler who allegedly took up arms driven by his patriotism during the war, wrote in his memoirs: 
This is the accepted version of a forthcoming article that will be published by Taylor \& Francis in Journal of North African Studies:

Accepted version downloaded from SOAS Research Online: http://eprints.soas.ac.uk/25444/

Tetouan for Spain! (...) [I proffer] a hymn of gratitude and praise to God as Columbus offered [it] in the Antilles, Cortés in the Andes, Balboa as he discovered the Pacific sea, Gama in Calcutta, and Magallanes in the Philippines; this cheer of triumph, glory and fortune will reverberate now in the whole universe, and it will awake the echoes of our name which still roam all over, in all the latitudes and all the continents through which our armies went awhile; and from America, Flanders, France, Germany and the whole of Italy, Greece, Constantinople, Asia and farther Oceania, from all the towns and cities in which the Spanish blood ran and in which the ashes of our ancestors rest a glorious sleep, will turn their sight onto Spain (Alarcón 1860, 430-31).

Alarcón's proclamation, as other contemporaries', established a link between the past Iberian imperial 'glories' and the 1860 Spanish victory over Tetouan. The chronicler's jingoistic cheers, similar to the main discourses which had arisen with the campaign propaganda, show that the war on Morocco was a balm to the imperial anxieties that permeated mid nineteenth-century Spanish discourses. Especially after the 'loss' of the majority of the American colonies in the past decades, the seizure of Tetouan came to confirm the "illusion of a new kind of colonialism" (Fradera 2002, 10). Alarcón's emphasis on the worldly admiration that the Spanish capture of Tetouan would have stimulated also reveals that the war represented for Spain the chance to contradict the northern European questioning of its 'civilization,' its ability to colonize, and its very Europeanness.

Other imperial resonances also permeated the occupied urban space of Tetouan, as the army plunged into altering the physiognomy of the city from the very outset of its capture. A number of streets and gates were renamed after both the early modern combats between Christians and Muslims in Iberia and the Reconquista. Bab Tüt and the sizeable 
This is the accepted version of a forthcoming article that will be published by Taylor \& Francis in Journal of North African Studies:

Accepted version downloaded from SOAS Research Online: http://eprints.soas.ac.uk/25444/

street that led to the gate were baptized after El Cid, an eleventh-century Castilian military leader appropriated as a Christian model warrior against the Muslims in their conquest of Iberia; and Bab al-Rumūz was named after the Catholic Kings. ${ }^{4}$ Sīdī 'Abd-Allah alBaqāl's $z \bar{a} w i y a$, located in the main square, was consecrated as a church under the name of Nuestra Señora de las Victorias (Our Lady of the Victories) as a tribute to the temple canonized by Cardinal Cisneros in sixteenth-century occupied Oran (Alarcón 1860, 569; Núñez de Arce 2003 [1860], 231). Cisneros had been the prominent advocate of Andalusis' mass conversions, the burning of Arabic manuscripts in reconquered Granada, and colonial expansion in the Maghrib.

The Reconquista provided a sound example of a precedent Christian victory against the Abode of Islam, and it was particularly suited on a local level because it arose the specter of the Reconquista that the ancestors of many Tetouanis had fled a few centuries before. Al-Andalus and the Reconquista also represented the cornerstones of the Spanish Africanism, whereby 'Africa' - mainly used as an eponym for Algeria and Morocco - had become the locus of the new Spanish imperial anxieties (Morales Lezcano 2006). Especially after 1830, as France colonized Algeria and Spain 're-discovered' its Andalusi past, Africanist theses advocated Spain's 'historical and geographical rights' vis-à-vis other European powers to colonize Morocco.

\footnotetext{
${ }^{4}$ A detailed list of the pre- and post-occupation names of Tetouani towers, gates, streets, mosques
} and other public places can be found in Daoud 1964a, V:321-24. 
This is the accepted version of a forthcoming article that will be published by Taylor \& Francis in Journal of North African Studies:

Accepted version downloaded from SOAS Research Online: http://eprints.soas.ac.uk/25444/

After having taken the military injured and choleric Spaniards to the Andalusian coast, the military doctor Nicasio Landa returned to occupied Tetouan, where he attended the inauguration of the church on February 12, 1860, and he asserted: "How could one not feel transported to the times of our ancestors, when they [Christians] conquered the cities of Andalucía [and] they consecrated to the Lord the mosques as though the first sign of victory (...)!" (Landa 1860, 166). Landa's reflection is to be understood within the framework of the aforementioned illusion of a new colonial venture that 'Africa' represented for mid-century Spain, and which was depicted as a continuation of an old enterprise which had been put aside for centuries (in which Spain had focused on the Americas and the Philippines), and was now resumed.

\section{Encountering Moroccans On The Ground: Towards Hispano-Moroccan Mimesis}

The prompt construction works that the Forces of the Occupation of Tetouan carried out indicates the urgent need that the Spaniards had to leave the imprint of their capture of Tetouan. As the colonial top-down initiatives developed, several processes led to a political transformation of those who were on the ground. Moroccan and specifically Tetouani people, notions and practices were not alien to these multi-layered processes, but on the contrary represented active agents of such transformation and thus of the course of the events which inaugurated Spanish colonialism in Morocco.

\section{The Tug of War with the Makhzan Diplomats}

The four emissaries acting on behalf of the Prince Mawlay al-'Abbās approached the Spanish chief Leopoldo O’Donnell's general headquarters five days after Tetouan was 
This is the accepted version of a forthcoming article that will be published by Taylor \& Francis in Journal of North African Studies:

Accepted version downloaded from SOAS Research Online: http://eprints.soas.ac.uk/25444/

occupied. Different encounters took place in the weeks to follow. In the second one, on February 16, the Makhzan diplomats met with outrage Queen Isabel II's provision to incorporate Tetouan to the Spanish domains. The diplomats and Mawlay al-'Abbās himself vehemently opposed the queen's condition, and used different strategies to coerce Spaniards that it was not in their interest for Tetouan to become Spanish.

After celebrating that second meeting in the outskirts of Tetouan, the emissaries requested to spend the night in Tetouan. In the afternoon, General Ríos took them around the occupied city to the newly established office of the electric telegraph and the Administration ovens, where he elucidated the technical devices introduced into Tetouan and presented the Spaniards as the harbingers of technological modernity. Far from showing interest, the envoys alluded to the British occupation of Gibraltar (ongoing since 1713), a particularly sensitive issue for the Spaniards, which encapsulated the status of Spain as a second-order world power (Alarcón 1860, 587). The diplomats are likely to have aimed at reminding the Spaniards of the British backing of the Makhzan, which included the British supply and training of the Moroccan army.

On February 23, the representative of the sultan to the foreign powers, the Tetouani Muhammad al-Khatīb, categorically rejected the incorporation of Tetouan to Spain. Al-Khatīb, who in the past weeks had led the negotiations to purchase British military supplies (Ibn Zaydān 1929, III: 492-95), asserted that "Europe w[ould] not consent it" (Alarcón 1860, 615-16). Al-Khatīb's powerful and concise affirmation implied that Spain was not European and, as such, it was a clear allusion to the northern European allegations on Spain's 'uncivilized' character, which delegitimized its colonial 
This is the accepted version of a forthcoming article that will be published by Taylor \& Francis in Journal of North African Studies:

Accepted version downloaded from SOAS Research Online: http://eprints.soas.ac.uk/25444/

ambitions in Morocco. The Makhzan's coercion strategies partly consisted in raising elements related to Spain's status as a second-order world power. The envoys of Mawlay al-'Abbās mobilized other issues, too.

In the evening of February 16, the emissaries were invited to a soirée held at notable Aḥmad al-Razīni’s mansion, where General Ríos had lodged. After some informal talk, the emissaries assured that the Spanish keeping of Tetouan heightened the risk of a civil war in Morocco. The interpreter and diplomat Aḥmad b. 'Ali Aba'yīr, who had already been appointed president of the Muslim councilors of the mixed city council, addressed the Spaniards to clarify what the emissaries were suggesting:

If the emperor ( $\ldots$ ) loses Tetouan, the parties overthrow the emperor, and if they overthrow the emperor, there will be a civil war in Morocco, and disorder and anarchy for many years, and you will have no one to address, and even if you address some, the others will not accomplish, and you will be compelled to keep fighting forever with no result whatsoever (Alarcón 1860, 594).

There were at least three 'Alawi rival claimants to the throne that the new sultan Sìdi Muhammad had come to hold after his father's death less than six months before, and the Moroccan population was increasingly divided. 'Abd al-Raḥmān b. Sulaymān posed the toughest threat, as he was finding support among the Berber tribes of southern Fes. Moreover, the sultan's elder brother was rising up in the south and trying to reach Marrakech (Martínez Antonio 2010, 73). Sīdī Muhammad's reputation had been tarnished at the 1844 defeat in the Battle of Isly against the French, while Sīdī Muhammad b. 'Abd-Allah, who had been in active support of the jihād party against the French in 
This is the accepted version of a forthcoming article that will be published by Taylor \& Francis in Journal of North African Studies:

Accepted version downloaded from SOAS Research Online: http://eprints.soas.ac.uk/25444/

western Algeria, was calling for jihād against the Spanish in the northeast of Morocco (Bennison 2002, 121-23).

The Moroccan envoys utilized and probably maximized the menace of the rival claimants to the throne in order to limit the conditions that the Spaniards were trying to impose, particularly the unacceptable incorporation of Tetouan to the Spanish domains. My point is not to insinuate that the claimants to the throne did not actually exist, but rather that the phantom of the 'civil war' was strategically and productively arisen by the Makhzan emissaries. As Thérèse Benjelloun (1991) and Mourad Zarrouk (2009) have held, Makhzan diplomacy historically displayed a wide variety of dissuasive tactics that included stressing and even exaggerating internal disunity.

Besides, Alarcón's narrative suggests that Moroccan urbanites, both the envoys and the Tetouani folk, mobilized the supposedly "fierce" character of rural tribes as a threat to the Spanish. In the first encounters, the Makhzan envoys exonerated themselves from the cruel war deeds, by arguing that it had been the "fierce tribes" who had committed them (Alarcón, 1860, 559). Alarcón wrote in his Diary that both Muslim and Jewish Tetouanis assured that the condition of incorporating Tetouan to Spanish domains would never be accepted by the Makhzan. Even if it was, he continued, "all the tribes of the empire will surround Tetouan (...) and will harass us day and night" (Alarcón 1860, $585)$.

Thus, the Moroccan diplomats employed external and internal elements to dissuade the Spaniards from their colonialist ambitions. Their explicit and implicit references to Great Britain hinted at the British opposition to the Spanish venture, and at 
This is the accepted version of a forthcoming article that will be published by Taylor \& Francis in Journal of North African Studies:

Accepted version downloaded from SOAS Research Online: http://eprints.soas.ac.uk/25444/

its formal and military support of the Makhzan. Moreover, the Makhzan envoys and the Tetouani population who had remained in the occupied city alluded to several other elements which jeopardized the Spanish permanence in Tetouan; namely the 'ferocity' of rural and tribal Moroccans, and the specter of a Moroccan civil strife provoked by the contentions among the "Alawi claimants to the throne.

The strategic mobilization of tribal 'ferocity' was not only that, however. It was also the expression of the conflictual character of the relations between the rural and the urban realm, which encapsulated a historical and political cleavage in Morocco. Tetouan was, together with Fes, Rabat and Salé, among the Moroccan cities traditionally termed as haḍ̄āyya for their being seats of Islamic culture and civilization, as opposed to Makhzan towns such as Tangier, Larache and Essaouira, which were seats of government or hosts to military garrisons (El Mansour 1990, 10). The hadā̄rī, literally 'civilized,' status of Tetouan encapsulated concepts of urbanity, that of being seats of Islamic culture, and comprised of Andalusi descendants. Although Andalusi populations had also settled in rural parts of Morocco, many of those who integrated hadārīyya towns constituted the $k h \bar{a} s \underline{s} a$, or the elite. Significantly, the elites of Moroccan (and Maghribi) urban centers were boastful of their Andalusi descent, born with an aura of refinement, culture, and urban 'civilization,' vis-à-vis the rural world.

What this means, then, is that both the Makhzan diplomacy and the Tetouanis who remained in the occupied city argued that the rural and tribal populations constituted a menace to the Spaniards as a way to coerce them, but also because the representation of the rural ethos as 'savage' informed a longstanding construction in the Moroccan socio- 
This is the accepted version of a forthcoming article that will be published by Taylor \& Francis in Journal of North African Studies:

Accepted version downloaded from SOAS Research Online: http://eprints.soas.ac.uk/25444/

political landscape. This article argues that the local people, notions and practices among the colonized were neither a-historical nor passive recipients of colonial dynamics and relations. It suggests that colonial knowledge and practice was not exclusively owned by the colonizers, but on the contrary was the result of various processes and actors including the colonized - which converged in the framework of nineteenth-century imperialism.

\section{Encountering Common Tetouanis: Shared Humanity and Exceptional}

\section{Unyieldingness}

As the negotiations between the politico-military leaders of both parties unfolded throughout February and the specter of the civil war and the 'ferocity' of tribal elements raised by the Makhzan officials and certain Tetouanis persuaded the Spaniards, their firsthand experience in Tetouan also influenced their colonialist views. While especially during the first battles Alarcón poeticized violence and praised war as a heroic and enjoyable practice, from the moment in which he walked in the streets of the just captured Tetouan he began to empathize with the suffering of the Tetouanis. When he witnessed the evidence of the mass looting which had taken place before the Spanish seizure, he admitted that the Spanish were partly the cause of the destruction he contemplated.

It was a pity to effectively contribute to the culmination of so much ravage, so much destruction. We had to a certain degree been the cause of such disasters, and far from commiserating with them - by lamenting them, perhaps - we heightened it with our devastating march. Each of those piles of ruins represented the fortune of a family, a fortune accumulated throughout long years of work, transmitted from parents to children and annihilated in [just] one moment (Alarcón 1860, 451). 
This is the accepted version of a forthcoming article that will be published by Taylor \& Francis in Journal of North African Studies:

Accepted version downloaded from SOAS Research Online: http://eprints.soas.ac.uk/25444/

This passage shows that the chronicler recognized that beneath the ruins over which he and the military personnel stepped might lie the result of the owners' hard work and inheritance. By acknowledging the Spaniards' responsibility in the perpetuation of the violence that hit the Tetouanis, Alarcón recognized the Tetouanis on the basis of their humanity and vulnerability vis-à-vis violence. Alarcón's humanization of the Tetouanis ultimately entailed a sort of 'human mimesis,' or the construction of sameness in the human condition which the colonial discourses often denied (Norris 2000). The allocation of grievability - that is, who is and should be mourned - differentially was (and is) at the core of the exclusionary conception of humanity at work in the (re)production of violence (Butler 2004).

Alarcón's grieving and humanization of Tetouanis was part of a multi-facetted transformation that advocated some restraint to the colonial enterprise. Alarcón expressed pity when he imagined the affection that the Tetouani owners may have felt for and within what appeared to him as only waste, a feeling that requires a degree of empathy that can only arise if the idea of radical difference is somehow softened. And yet, the author from Granada did not perceive Tetouanis as victims in need of commiseration. On the contrary, he admired their resilient attitude. He exclaimed:

Great silence, decent proudness, majestic indifference, heroic disdain. Oh! The attitude of these savages is sublime (...) Savages, I said, and the truth is that I cannot conceive more civilization than the one Muslims reveal (...) this indestructible superiority that their unblemished religious faith gives them (...) they exert their rational faculties with as much wisdom as Socrates and Cato, or as the Christian martyrs. All of this proves that Moors are unconquerable (...) They are neither fearful nor provocative. Their conviction that they will never be our slaves is sufficient to them. (Alarcón 1860, 527-28). 
This is the accepted version of a forthcoming article that will be published by Taylor \& Francis in Journal of North African Studies:

Accepted version downloaded from SOAS Research Online: http://eprints.soas.ac.uk/25444/

Alarcón rectified the adjective "savage' that he firstly allocated to Muslims" "silence," "proudness" and "indifference," and came to conceive their strength vis-à-vis the Spanish conquerors as the sign of their "civilization," their "indestructible superiority," "rational faculties," and, climactically, their unconquerability. Captain Eduardo Soler y Ovejero provided similar insights in his Descriptive Memory of an Itinerary Project from Tetouan to al-Kasr and Fes, where he suggested that Muslims' unyielding attitude toward their subjection to "civilized customs" made their colonization more difficult than that of "any other people" (Soler y Ovejero 1862, 57). For his part, the journalist Gaspar Núñez de Arce asserted that Moroccans' "character," which manifested in their "eloquent silence," the "scowl" in their looks, and their "dignity," was "worthy of consideration and respect" (Núñez de Arce 2003 [1860], 233).

The attitudes that the Spaniards came to admire can be taken to embody different forms of inkimāsh or sorts of internal hijra, consistent on an "inward religio-spiritual movement or withdrawal employed by those Muslims who lacked the will or the means to depart from their homeland" (Clancy-Smith 1994, 7). As mentioned before, the political and religious authorities had urged Tetouanis to adopt hijra (migration) on the eve of the Spanish seizure. Those who did not abandon the city thus came to be considered as necessarily willing to co-operate with the Spaniards. Mufaḍdal Afaylāl, a sharīf and well-known religious authority in Tetouan who held local and Makhzan authorities ultimately responsible for the Spanish occupation of the city, branded the notables and fuqahā' who did not migrate out of occupied Tetouan "Christianized" (mutanāṣira) (Afaylāl, n.d., 35). Contradicting Afaylāl's accusations, Mohamed Daoud's influential work also conveyed the idea that Tetouanis chose by majority one path, which the 
This is the accepted version of a forthcoming article that will be published by Taylor \& Francis in Journal of North African Studies:

Accepted version downloaded from SOAS Research Online: http://eprints.soas.ac.uk/25444/

historian undoubtedly thought of as proof of Tetouanis' political action against the Spanish occupation (Daoud 1964, IV:127). Instead, what the Spaniards' writings show is that among those who remained in Tetouan there were some who adopted forms of internal exile, which can be seen as "means of coping and therefore of endurance," of "safeguarding the potentialities of Islam" (Berque 1978, 419), and therefore as forms of political action. ${ }^{5}$

The admiration that some Muslims’ inkimāsh arose among Spaniards significantly reinforced the idea of the difficulties that the colonial endeavor would have to face if the incorporation of Tetouan to the Spanish domains and the advancement in the Moroccan territory were to continue. The attitude of "passive resistance" displayed by some Tetouanis (Salazar 1860) bolstered the specter of the other menaces that the Makhzan envoys had raised; all of which became magnified with the suspension of the negotiations, the polarization of attitudes and the pressing siege of Tetouan sponsored by the Makhzan.

\section{The New Tugs of War: Consolidating Spanish Colonialism Through the}

\section{Pragmatic Restraint Inspired by Moroccan People and Politics}

In view of the Makhzan's opposition to the incorporation of Tetouan to Spain, Queen Isabel II ordered O'Donnell to suspend negotiations and resume the war. The queen commanded the recently appointed 'Duke of Tetouan' to continue the campaign to

\footnotetext{
${ }^{5}$ Similar reactions to Algerians' attitudes can be found in French military authorities' writings.
} See Marnia Lazreg $(1994,24)$. 
This is the accepted version of a forthcoming article that will be published by Taylor \& Francis in Journal of North African Studies:

Accepted version downloaded from SOAS Research Online: http://eprints.soas.ac.uk/25444/

Tangier, and banned him from negotiating the evacuation of Tetouan (Burdiel 2010, 633).

In peninsular Spain, the liberal press and the opposition parties continued to wave the bellicose calls which had bestowed them considerable political gain during the campaign. O'Donnell and the military officials, caught between those forces, decided to make use of a further tool to press Moroccans to accept the Spanish conditions, and on February 25 and 26 the navy bombed the ports of Larache and Asilah.

The Makhzan, for its part, sieged Tetouan. By the end of February and the beginning of March, as a consequence of the hostilities with the neighboring Busemeler tribe, Spanish soldiers were killed in the roads of the outskirts of Tetouan and within the city. In addition, a blockage on the entry of food supplies was imposed on the city. Members of the sultan's 'Abīd al-Bukhārī corps wandered in the outskirts of Tetouan to avoid anyone entering the city to provide supplies. Alarcón declared:

There is no defense against this, (...) not even forty thousand soldiers established both in the inner and the outer side of this stronghold would be able to guarantee the life and the property of its inhabitant from the perfidy (or the patriotism!) of Muslims (...) Moors' attitude with regards to the Spanish invasion is the same we adopted towards the French invasion -think of what happened back then in the peninsula and make a guess of what can happen to us in Africa (Alarcón 1860, $620-21)$.

Alarcón's words show not only how different these declarations sound from his previous grandiloquent exclamations, but also reveal his admiration towards Moroccans' attitude, and his blurring of Hispano-Moroccan differences by resorting to analogy. As with the previous citation, he preliminarily identified what the Spanish were unable to defend from as Muslims' "perfidy," which he immediately after conceived as the antithetic and 
This is the accepted version of a forthcoming article that will be published by Taylor \& Francis in Journal of North African Studies:

Accepted version downloaded from SOAS Research Online: http://eprints.soas.ac.uk/25444/

remarkably positively connoted term, i.e., patriotism (followed by an exclamation sign).

Moreover, the chronicler went on to construct similarity between the Spanish and the Moroccans on the basis of patriotism, or resistance, against foreign occupiers, by referring to no less than the so-called War of Independence against the Napoleonic occupation of Spain (1808-1814). Rather than emphasizing difference, then, Alarcón gave way to a mimesis that recognized Hispano-Moroccan similarity, on the grounds of the fight against a foreign power's occupation.

In the increasingly tense political context in peninsular Spain, the defense of pacifist positions did not satisfy many sectors. The liberal newspaper La Iberia branded the chroniclers of war - including Alarcón and Núñez de Arce - the "apostles of peace." Alarcón criticized the politicians in Madrid who dictated the way to proceed in the campaign and the peacemaking, and affirmed that they lacked knowledge of "what only having a close view can be understood" (Alarcón 1860, 561). For his part, General Prim, the hero of the campaign, addressed a letter to his politician colleagues, suggesting that those who waved the conquest thesis in the peninsula were "ignorant" (cited in: Burdiel 2010, 635). Partly replicating the words of warning that the Moroccan authorities had pronounced during the various encounters, General Prim mentioned the many disadvantages and the few advantages that the incorporation of Tetouan into the Spanish monarchy would entail.

Barbara Fuchs $(2001,39)$ has contended that the writers of the early modern Spanish chronicles which narrated the empire-building events claimed their authority insofar as eyewitnesses who "saw" what happened "in reality," and opposed it to the 
This is the accepted version of a forthcoming article that will be published by Taylor \& Francis in Journal of North African Studies:

Accepted version downloaded from SOAS Research Online: http://eprints.soas.ac.uk/25444/

"imagination" that supposedly shaped peninsular Spanish subjects' understanding of what imperialism entailed. By the same token, the first-hand experience that these civilian and military Spaniards lived (including their exposure to Moroccan diplomats' and common Tetouanis' claims and attitudes) was what drove them to self-identify, empathize, and admire Moroccans to highlight familiarity, sameness, and to trace analogies in history and behavior, and ultimately advocate restraint in the colonialist enterprise. On his way to peninsular Spain, where he aimed at fighting the new battles against the peninsular conquest fervor, Alarcón insisted that "the war of Africa, after having forged the glory of the nation w[ould] end up, if it [went] on, causing its wreck" (Alarcón 1860, 673).

On March 11, as the Army of Africa finally advanced toward Tangier, a bloody battle took place in the plain of Samsa against some newly arrived Rifian contingents. The day after the Moroccan defeat, the emissaries of Mawlay al-'Abbās approached the Spanish camp. They apologized for the attack of the Rifians which, they held, contradicted Mawlay al-'Abbās' orders. The "Rifian warriors" were said to have ignored the warning of the prince of the blood, after having condemned Mawlay al-'Abbās' unwillingness to fight the 'infidels' as cowardice (Alarcón 1860, 659-60). O’Donnell proceeded to ask the queen to reconsider the incorporation of Tetouan into the Spanish lands, and the new provision established that Tetouan would be occupied until the war indemnity was completed. But negotiations were once again suspended after the Moroccan delegates refused the temporary occupation of Tetouan. 
This is the accepted version of a forthcoming article that will be published by Taylor \& Francis in Journal of North African Studies:

Accepted version downloaded from SOAS Research Online: http://eprints.soas.ac.uk/25444/

The march to Tangier was resumed on the eve of the beginning of the holy month of Ramadan of the year 1276 of the hijri calendar, March 23 of the Gregorian calendar. The Moroccan army prevented Spaniards' advance across the plain of Wad Ras, where yet another bloody battle took place. Mawlay al-'Abbās demanded another encounter, and shortly after requested to postpone it due to the praying prescriptions of Ramadan. The Makhzan's “diplomacy of wearing down” (Zarrouk 2009, 26) continued by blaming the "fierce" Rifian countrymen for any attack, and by endeavoring to postpone the encounters by alleging religious duties. Eventually, the conference took place two days later, when the preliminary peace treaty was signed on March 25, 1860. The official ratification would take place a month later, on April 26, two months and twenty days after Tetouan was occupied.

The Spanish opposition parties, in their struggle against the figure of O'Donnell and his La Unión Liberal, insisted on the insignificant gain that such a bombastically enhanced war provided for Spain, and they coined the maxim 'the great war of petty peace.' O'Donnell, in keeping track of the occupation and the further complications that continued to arise in Tetouan, kept fighting the dialectical wars in a parliamentary battle. In June 1860, he replied to deputy González Bravo’s plea in the Spanish Cortes by making the Makhzan envoys' words his own:

Does Your Honor know why I renounced the capture of Tangier? Because the occupation of Tangier would have involved overthrowing the Moroccan sultan, and a civil war would have erupted in Morocco. And this, which seems a great advantage to us, entailed a major disadvantage; I do not know where it could have led us. On the day in which no government had existed in Morocco an eternal war would have begun against that empire, during which our convoys would have been 
This is the accepted version of a forthcoming article that will be published by Taylor \& Francis in Journal of North African Studies:

Accepted version downloaded from SOAS Research Online: http://eprints.soas.ac.uk/25444/

intercepted, our detachments attacked; we would have been harassed and obliged to fight. How long? This I know not (cited in: Garrido Quijano 2014, 241-42).

The Spanish war on Tetouan that the party of O'Donnell had put on in an attempt to achieve the party's governmental consolidation turned out, in the end, to represent a threat to it. In the aftermath of the peacemaking, the very colonial expectations that the warmongering discourses had contained before and during the campaign stimulated the re-emergence of disunity among the multiple Spanish political and social fractions. As the 'apostles of peace' and General Prim, O'Donnell ventriloquized the Makhzan diplomats' warnings, which the attitudes of some common Tetouanis and the difficulties that the Makhzan's siege of Tetouan had strengthened.

\section{Conclusion}

The main twofold goal of the article has been to nuance the idea that the Spanish colonizers had unlimited power and the Moroccan colonized had no or little scope of action; and to highlight the critical role that Moroccan and specifically Tetouani people, notions, and practices played in shaping the colonial processes and rule. For that end, the article has traced the political transformation of the Spaniards who were on the ground during the preliminary stage of the 1860 occupation of Tetouan. Such political transformation was a consequence of various interrelated processes, amongst which I have highlighted three main elements: the Spaniards' acknowledgement of the peril of a civil strife that a prolonged occupation of Tetouan and the occupation of other Moroccan territories could lead to, and which would complicate the venture; connected to the Spanish perception of Moroccans' 'unconquerability'; and the increasing empathy and 
This is the accepted version of a forthcoming article that will be published by Taylor \& Francis in Journal of North African Studies:

Accepted version downloaded from SOAS Research Online: http://eprints.soas.ac.uk/25444/

self-identification with Tetouanis that the first-hand experience produced in those Spaniards.

Makhzan authorities and Tetouani urbanites mobilized internal and external menaces to coerce the Spaniards. They referred to Spain's second-order world power and to the British backing of the Makhzan. They also built upon Europeans' prejudices regarding Moroccan political disunity and 'anarchy,' rural tribesmen's 'ferocity' or the extreme religious 'fanaticism,' which represented a smart strategy that limited the Spanish colonial ambitions - at least in the short run. Such a strategy would eventually become a double-edged sword, as in the long run European powers used those claims to legitimize colonial intervention. While historiographical (post)colonial narratives have tended to uniquely ascribe the construction of such tropes to 'the colonizers,' I have argued that Moroccan authorities and people were active agents in their inception and spread. This is not, of course, valid all the colonial discourses. For example, the dichotomy between bled al-makhzan versus bled al-siba, which divided Morocco on the basis of a territorially-defined allegiance to the Makhzan and the rebellion against it, was transferred from French Algeria onto French and, to a lesser extent, Spanish Morocco.

The central claim of the article is that the colonized populations and politics shaped the course of the colonial events. Without losing sight of the uneven imperial macro-structures in which they operated, this article suggests that the colonized populations were not located out of history, and the local political notions and practices are to be acknowledged as key in the processes which conditioned colonialism. In the preceding pages, I have held that the notion of the rural 'savagery,' the contested nature 
This is the accepted version of a forthcoming article that will be published by Taylor \& Francis in Journal of North African Studies:

Accepted version downloaded from SOAS Research Online: http://eprints.soas.ac.uk/25444/

of the power and the legitimacy of sultan, and religio-spiritual-cum-political practices such as inkimāsh outstandingly shaped the nature of the mid nineteenth-century Spanish colonial intervention. I have also emphasized the Spaniards' imitation, ventriloquization, identification, admiration and appropriation of Moroccan discourses, practices, and attitudes, which show the chief role that different categories of Moroccans played a in the Spanish occupation of Tetouan, both individually and collectively.

Yet the political transformation of the Spaniards to which the Moroccans contributed did not ultimately undermine the larger colonial scope of the venture. The pragmatic restraint that both the civilian and the military Spaniards advocated weighted Spain's colonial limitations and ambitions. The pacifist theses that the so-called 'apostles of peace' purported in their chronicles and the moderate positions that the chiefs of the Army of Africa advocated, partly due to the influence of both Makhzan envoys and Tetouani civilians, were not well received by the colonialist sectors of peninsular Spain. In the long run, however, the former's pragmatism paved the way for consolidating the colonial penetration into Morocco, which was in turn left suffocated in a rampant economic crisis and a political entanglement that would lead into popular protests throughout the following decades (Sebti 1991; Bazzaz 2010, 50-81).

Not only Spain took advantage of the infrastructures set in place during the occupation of Tetouan, however. Although the British had opposed and limited the reach of the Spanish war on Tetouan, the 1861 treaty benefitted the British intervention in Moroccan customs houses throughout the second half of the nineteenth century. Besides, the Alliance Israélite Universelle, founded in Paris in 1860, was able to establish its first 
This is the accepted version of a forthcoming article that will be published by Taylor \& Francis in Journal of North African Studies:

Accepted version downloaded from SOAS Research Online: http://eprints.soas.ac.uk/25444/

worldwide school in Tetouan in December 1862 party because the Spanish occupation of Tetouan had already summoned a community of Jews who had attended school (Cohn and Munk 1927, 2-3).

Complex historical processes such as Spanish colonialism in Morocco are characterized by dynamic power structures and systems, which can only be grasped by acknowledging the political contradictions, ambivalences, and dissensions. To provincialize Europe, as Dipesh Chakrabarty (2000) famously inspired us to do, I have come to believe, is to deal with a historical Europe - thus, a non-almighty Europe. To provincialize Europe is neither to avoid the specific trajectories of its expansion, nor to fetishize them (Cooper 2005, 30), and that includes acknowledging the role of the colonized people and politics in shaping colonialism. The local realm, I have argued, is a productive site to pursue such an endeavour.

\section{Bibliography}

Afaylāl, Sīdī Mufaḍḍal. n.d. "The Diary of Sīdī Mufaụḍal Afaylāl.” Al-Khizāna alDawūdīyya (Daoudian Archive).

Alarcón, Pedro Antonio de. 1860. Diario de un testigo de la guerra de África: ilustrado con vistas de batallas, de ciudades y paisajes, tipos, trajes y monumentos, con el retrato del autor y de los principales personajes, copiados de fotografias... Madrid: Imprenta y Librería de Gaspar y Roig.

Assaoud, Abdelaziz. 2010. “Harb Isbānīā 'Alā Al-Maghrib 'Ām 1860 Wa 'Awāqibiha Al-Wakhīma (The Spanish War on Morocco in 1860 and Its Serious 
This is the accepted version of a forthcoming article that will be published by Taylor \& Francis in Journal of North African Studies:

Accepted version downloaded from SOAS Research Online: http://eprints.soas.ac.uk/25444/

Repercussions).” In Nadwah Dawlīyah: Harb Tițwān, 1859-1860 (International Conference on the War of Tetouan, 1859-1860), 129-40. Rabat: Mandūbīyah alSāmīyah li-Qudamā’ al-Muqāwimīn wa-A ‘ḍā’ Jaysh al-Taḥrīr.

Bazzaz, Sahar. 2010. Forgotten Saints: History, Power, and Politics in the Making of Modern Morocco. Cambridge, Mass.: Harvard University Press.

Benjelloun, Thérèse. 1991. Visages de la diplomatie marocaine depuis 1844. Casablanca: Editions EDDIF.

Bennison, Amira K. 2002. Jihad and Its Interpretations in Pre-Colonial Morocco: StateSociety Relations during the French Conquest of Algeria. London; New York: Routledge Curzon.

Berque, Jacques. 1978. L'intérieur du Maghreb, XVe-XIXe siècle. Paris: Gallimard.

Bhabha, Homi. 1997. "Of Mimicry and Man: The Ambivalence of Colonial Discourse." In Tensions of Empire: Colonial Cultures in a Bourgeois World, edited by Ann Stoler and Frederick Cooper, 152-60. Berkeley: University of California Press.

Burdiel, Isabel. 2010. Isabel II: una biografía (1830-1904). Madrid: Taurus.

Butler, Judith. 2004. Precarious Life: The Powers of Mourning and Violence. London; New York: Verso.

Cagigas, Isidro de las. 1952. Tratados y convenios referentes a Marruecos. Madrid: Instituto de Estudios Africanos. 
This is the accepted version of a forthcoming article that will be published by Taylor \& Francis in Journal of North African Studies:

Accepted version downloaded from SOAS Research Online: http://eprints.soas.ac.uk/25444/

Calderwood, Eric Stickley. 2011. "Writing the Hispano-Moroccan War of 1859-1860:

Spanish and Moroccan Reflections on Spanish Colonialism in Morocco.” Ph.D., Massachusetts: Harvard University.

Chakrabarty, Dipesh. 2000. Provincializing Europe: Postcolonial Thought and Historical Difference. Princeton, N.J.: Princeton University Press.

Clancy-Smith, Julia Ann. 1994. Rebel and Saint: Muslim Notables, Populist Protest, Colonial Encounters (Algeria and Tunisia, 1800-1904). Berkeley: University of California Press.

Cohn, Hermann, and S Munk. 1927. Mours des Juifs et des Arabs de Tétuan (Maroc). Paris: Lipschutz.

Cooper, Frederick. 2005. Colonialism in Question: Theory, Knowledge, History. Berkeley: University of California Press.

Daoud, Mohamed. 1964a. Tārīkh Tițwān (The History of Tetouan). Muhammad V University. Vol. V. Rabat.

1964b. Tārīkh Titwān (The History of Tetouan). Muhammad V University. Vol. IV. Rabat.

El Mansour, Mohamed. 1990. Morocco in the Reign of Mawlay Sulayman. Wisbech: Middle East \& North African Studies Press.

Farneti, Roberto. 2015. Mimetic Politics: Dyadic Patterns in Global Politics. Michigan: Michigan University Press. 
This is the accepted version of a forthcoming article that will be published by Taylor \& Francis in Journal of North African Studies:

Accepted version downloaded from SOAS Research Online: http://eprints.soas.ac.uk/25444/

Fradera, Josep Maria. 2002. "Prólogo: La Formación de Un Espacio Colonial Repensada.” In Marruecos Y El Colonialismo Español [1859-1912] De La Guerra de África a La "penetración Pacífica," edited by Eloy Martín Corrales, 9-13. Barcelona: Edicions Bellaterra.

Fuchs, Barbara. 2001. Mimesis and Empire: The New World, Islam, and European Identities. Cambridge; New York: Cambridge University Press.

Garrido Quijano, Óscar. 2014. “Aproximación a Los Antecedentes, Las Causas Y Las Consecuencias de La Guerra de África (1859-1860) Desde Las Comunicaciones Entre La Diplomacia Española Y El Ministerio de Estado.” Instituto Universitario General Gutiérrez Mellano - UNED.

Ibn Khālid al-Nāṣirī, Aḥmad. 1997. Kitāb al-Istiqșā li-Akhbār Duwal al-Maghrib al-Aqșā (The Book of Investigation about the Dynasties of Morocco). Vol. 9. Casablanca: Ministry of Culture and Communications.

Ibn Zaydān, 'Abd al-Raḥmān b. Muḥammad. 1929. Itḥāf a 'lām al-nās bi-jamāl akhbār hădirira-t Miknās (A Presentation of Enlightened People with the most beautiful Reports of the City of Meknes). Vol. III. Rabat: 'Abbās al-Tinnān̄i.

Irigaray, Luce. 1996. This Sex Which Is Not One. Ithaca (N.Y.): Cornell University Press.

Kelly, Michael. 1998. Encyclopedia of Aesthetics. Vol. III. New York: Oxford University Press. 
This is the accepted version of a forthcoming article that will be published by Taylor \& Francis in Journal of North African Studies:

Accepted version downloaded from SOAS Research Online: http://eprints.soas.ac.uk/25444/

Landa, Nicasio. 1860. La campaña de Marruecos: memorias de un médico militar. Madrid: Imprenta de Manuel Álvarez.

Lazreg, Marnia. 1994. The Eloquence of Silence: Algerian Women in Question. London: Routledge.

Martínez Antonio, Francisco Javier. 2010. La otra Guerra de África: cólera y conflicto internacional en la olvidada expedición militar de Francia a Marruecos en 1859. Ciudad Autónoma de Ceuta: Archivo General.

Martin-Márquez, Susan. 2008. Disorientations: Spanish Colonialism in Africa and the Performance of Identity. New Haven, Conn.; London: Yale University Press.

Morales Lezcano, Víctor. 2004. "Pedro Antonio de Alarcón en el torbellino de la Guerra de África.” In Pedro Antonio de Alarcón y la guerra de África: del entusiasmo romántico a la compulsión colonial, edited by José Antonio González Alcantud and Manuel Lorente Rivas, 61-84. Barcelona: Anthropos.

2006. "Las Relaciones Hispano-Marroquíes En El Siglo XIX.” In Historia de Marruecos: De Los Orígenes Tribales Y Las Poblaciones Nómadas a La Independencia Y La Monarquía Actual, 181-202. Madrid: La esfera de los libros.

Norris, Margot. 2000. Writing War in the Twentieth Century. Charlottesville: University Press of Virginia.

Núñez de Arce, Gaspar. 2003. Crónicas periodísticas: Guerra de África, 1859-1860. Edited by María Antonia Fernández Jiménez. Madrid: Biblioteca Nueva. 
This is the accepted version of a forthcoming article that will be published by Taylor \& Francis in Journal of North African Studies:

Accepted version downloaded from SOAS Research Online: http://eprints.soas.ac.uk/25444/

Palaver, Wolfgang. 2013. René Girard's Mimetic Theory. East Lansing: Michigan State University Press.

Polat, Necati. 2012. International Relations, Meaning and Mimesis. Hoboken: Taylor and Francis.

Ricard, Robert. 1968. “Cartas de Ricardo Ruiz Orsatti a Galdós Acerca de Marruecos (1901-1910).” Anales Galdosianos Año III 3:99-115.

Rodríguez Esteller, Omar. 2002. “La Intervención Española de Las Aduanas Marroquíes (1862-1885).” In Marruecos Y El Colonialismo Español [1859-1912] De La Guerra de África a La "penetración Pacífica," edited by Eloy Martín Corrales, 79-132. Barcelona: Edicions Bellaterra.

Romano, Julio. 1933. Pedro Antonio de Alarcón: el novelista romántico. Madrid: EspasaCalpe.

Salazar, Francisco. 1860. “E1 Noticiero de Tetuán 07/12/1860.” Imprenta de García Y Contilló, July 12, 1860. Biblioteca Nacional de España.

Sebti, Abdelahad. 1991. "Chronique de La Contestation Citadine: Fès et La Révolte Des Tanneurs, 1873-1874" 29 (2):283-312.

Soler y Ovejero, Eduardo. 1862. Memoria Descriptiva de Un Proyecto de Itinerario de Tetuán a El Alcázar Y Fez. Barcelona: Imprenta del Diario de Barcelona.

Taussig, Michael T. 1993. Mimesis and Alterity: A Particular History of the Senses. New York: Routledge. 
This is the accepted version of a forthcoming article that will be published by Taylor \& Francis in Journal of North African Studies:

Accepted version downloaded from SOAS Research Online: http://eprints.soas.ac.uk/25444/

Vilar, Juan Bautista. 1985. Tetuán en el resurgimiento judío contemporáneo (18501870): aproximación a la historia del judaísmo norteafricano. Caracas: Asociación Israelita de Venezuela-Centro de Estudios Sefardíes de Caracas.

Zarrouk, Mourad. 2009. Los traductores de España en Marruecos, 1859-1939. Barcelona: Bellaterra. 